\title{
PENGARUH MOTIVASI DAN KEBIASAAN BELAJAR TERHADAP HASIL BELAJAR GEOGRAFI SISWA SMA NEGERI DI KOTA SINGARAJA
}

\author{
Anna Sharah ${ }^{1}$, Ida Bagus Made Astawa ${ }^{2}$ \\ Pendidikan Geografi, Universitas Pendidikan Ganesha, Indonesia
}

\section{A R T I C L E I N F O}

Article history:

Received 2 April 2018

Received in revised form

6 Agustus 2018

Accepted 12 Agustus 2018

Available online 31 Agustus 2018

\section{Kata Kunci:}

motivasi

kebiasaan

hasil

belajar.

Keywords:

Motivation

Habits

Learning

Outcome

\section{A B S T R A C T}

This research aims to analyze:

(2) learning habits towards learning outcomes,

and study habits towards theresultsof learning geography sman in Singaraja City. Use

(1) learning motivation towards learning outcomes,

$$
\text { (3) the influence of motivation }
$$

their data ional analysis regression. The results showed that (1) there is a positive influence between the motivation of learning towards the learning outcomes of students. (2) there is a positive influence between the habit of learning towards the learning outcomes of students. (3) there are altogether positive influence between motivation and learning habits toward student learning outcomes with the determinants of $74.2 \%$. Based on the results of the study, it was concluded that the motivations and habits learned very influential towards the results of the study of geography students.

\footnotetext{
* Corresponding author.

E-mail addresses: $\underline{\text { annasharah@gmail.com (Penulis Pertama), idabagusmadeastawa@yahoo.com (Penulis Kedua) }}$
} 



\section{Pendahuluan}

Pendidikan adalah suatu kegiatan yang dilakukan secara sengaja, berkesinambungan dan berencana dengan tujuan untuk mengembangkan sikap dan perilaku yang diinginkan. Sebagai lembaga formal, sekolah merupakan wadah dalam rangka pencapaian tujuan pendidikan tersebut. Sebagai lembaga formal, sekolah merupakan wadah dalam rangka pencapaian tujuan pendidikan tersebut. Melalui sekolah, siswa akan memperoleh pengetahuan dan kemampuan berpikir, memperoleh keterampilan dan membentuk sikap siswa. Semua hal tersebut diperoleh melalui proses belajar mengajar yang diikuti siswa dalam kelas (Sardiman, 2001:57)

Pendidikan memiliki tujuan-tujuan yang digunakan pendidik sebagai pedoman dalam merencanakan, melaksanakan, dan mengevaluasi pembelajaran yang akan diimplementasikan. Melalui pendidikan siswa dapat memperoleh nilai-nilai sikap, pengetahuan, dan keterampilan yang secara utuh dipelajari di sekolah. Seluruh kompetensi terebut akan berguna bagi siswa dalam kehidupannya di keluarga maupun masyarakat.

Kegiatan belajar mengajar merupakan kegiatan yang paling pokok dari keseluruhan proses pendidikan di sekolah. Ini berarti bahwa berhasil tidaknya pencapaian tujuan pendidikan banyak bergantung pada pembelajaran yang dialami oleh siswa sebagai anak didik. Menurut Slameto (2003:2), belajar ialah suatu proses yang dilakukan seseorang untuk memperoleh suatu perubahan tingkah laku yang baru secara keseluruhan, sebagai hasil pengalaman sendiri dalam interaksi dengan lingkungannya. Hasil belajar dapat dipengaruhi oleh dua faktor, yaitu faktor internal dan faktor eksternal. Faktor eksternal adalah faktor yang berasal dari luar diri siswa atau berasal dari lingkungan, baik lingkungan sosial maupun lingkungan non sosial. Sementara faktor internal merupakan faktor yang berasal dari dalam diri siswa itu sendiri, termasuk didalamnya motivasi dan kebiasaan belajar (Sardiman,2001:39).

Sardiman (2001:75) mengemukakan, motivasi dalam kegiatan belajar dapat diartikan sebagai keseluruhan daya penggerak dalam diri siswa yang menimbulkan kegiatan belajar, yang menjamin kelangsungan dari kegiatan belajar dan yang memberikan arah pada kegiatan belajar, sehingga tujuan yang dikehendaki oleh subjek belajar itu dapat tercapai.

Selain motivasi, kebiasaan belajar juga merupakan faktor yang mempengaruhi siswa dalam belajar. Sebagian prestasi belajar ditentukan oleh sikap dan kebiasaan belajar. Whitherington, 1999 (dalam Djaali, 2009:127), menyatakan bahwa kebiasaan merupakan cara bertindak yang diperoleh melalui belajar secara berulang-ulang, yang pada akhirnya menjadi menetap dan bersifat otomatis.

Kota Singaraja memiliki 4 SMA Negeri yang sementara ini dinilai memiliki keunggulaan dibandingkan swasta. Hal tersebut dapat dilihat dari pilihan utama para lulusan SMP yang memprioritaskan untuk melanjutkan pendidikannya di SMA Negeri. SMA swasta umumnya mendapatkan siswa yang tidak diterima di SMA Negeri. Berkenaan dengan itu, hasil belajar siswa di SMA Negeri seharusnya juga lebih baik dibandingkan SMA Swasta termasuk dalam pembelajaran geografi. Namun realitasnya tidaklah demikian. 
Berdasarkan hasil observasi awal yang dilakukan, Kriteria Ketuntasan Minimal (KKM) yang diperoleh siswa dalam mata pelajaran geografi siswa SMA Negeri di Kota Singaraja sudah mencapai nilai di atas 60 (68-72). Namun demikian, hasil KKM tersebut banyak yang diperoleh siswa melalui remidi. Pada saat pembelajaran berlangsung siswa kurang memperhatikan pelajaran geografi. Motivasi belajar siswa kurang terhadap pelajaran geografi. Selain itu, banyak siswa yang tidak memanfaatkan waktu luang yang mereka miliki untuk belajar, banyak siswa yang tidak memiliki kebiasaan belajar yang baik.

Fenomena yang dikemukakan tersebut sejalan dengan yang dikemukakan sejumlah pihak. Yani, 2010 (dalam Rifani, 2013:4) mengemukakan permasalahan pada pembelajaran geografi di sekolah teridentifikasi ada dua, yaitu geografi dianggap sebagai mata pelajaran yang tidak menarik dan pembelajaran geografi di sekolah dinilai belum mengembangkan daya nalar peserta didik secara optimal.

Pembelajaran geografi yang dianggap sebagai mata pelajaran tidak menarik tersebut akan berdampak pada hasil belajar siswa. Hal ini akan menyebabkan rendahnya hasil belajar dan penguasaan materi oleh siswa. Adanya anggapan geografi sebagai mata pelajaran yang tidak menarik, motivasi siswa yang kurang serta kebiasaan belajar yang salah mengakibaktan hasil belajar yang didapat terkadang jauh dari yang diharapkan. Berkenaan dengan itu sangat penting untuk mengungkap bagaimana motivasi dan kebiasaan belajar siswa dalam pembelajaran geografi. Azainil (2014) dalam penelitiannya menyimpulkan bahwa motivasi dan kebiasaan belajar berpengaruh signifikan terhadap hasil belajar.

Pertanyaannya, apakah semua siswa SMA Negeri di Kota Singaraja memiliki motivasi dan kebiasaan belajar yang rendah dalam mata pelajaran geografi yang menyebabkan rendahnya hasil belajar mereka. Berkenaan dengan itu, dilakukan penelitian dengan judul "Pengaruh Motivasi dan Kebiasaan Belajar terhadap Hasil Belajar Geografi Siswa pada SMA Negeri di Kota Singaraja".

Berdasarkan latar belakang tersebut maka dapat dirumuskan permasalahan (1) Bagaimana motivasi belajar siswa SMA Negeri di Kota Singaraja dalam pembelajaran Geografi, (2) Bagaimana kebiasaan belajar siswa SMA Negeri di Kota Singaraja dalam pembelajaran Geografi, (3) Bagaimana pengaruh motivasi dan kebiasaan belajar terhadap hasil belajar Geografi siswa SMA Negeri di Kota Singaraja. Berdasarkan rumusan masalah tersebut maka tujuan penelitian ini dapat dikemukakan, yaitu (1) Untuk menganalisis motivasi belajar siswa SMA Negeri di Kota Singaraja dalam pembelajaran Geografi, (2) Untuk menganalisis kebiasaan belajar siswa SMA Negeri di Kota Singaraja dalam pembelajaran Geografi, (3) Untuk menganalisis pengaruh motivasi dan kebiasaan belajar terhadap hasil belajar Geografi siswa SMA Negeri di Kota Singaraja.

\section{Metode}

Rancangan yang digunakan pada penelitian ini adalah rancangan penelitian korelasional. Penelitian ini berlokasi di Kota Singaraja, Kabupaten Buleleng, yaitu pada SMA-SMA Negeri yang berada di Kota Singaraja. Berdasarkan maslah yang ada, objek 
dalam penelitian ini adalah pengaruh motivasi dan kebiasaan belajar terhadap hasil belajar siswa. Berkenaan dengan itu, subjek dalam penelitian ini adalah siswa SMA Negeri di Kota Singaraja. Siswa yang digunakan adalah siswa kelas XI. Sehingga terdapat popoulasi yaitu 260 siswa dari 4 SMA Negeri di Kota Singaraja. Metode yang digunakan dalam pengambilan sampel adalah random sampling, pemilihan kelas dilakukan dengan pertimbangan setiap kelas di masing-masing sekolah tidak terdapat kelas unggulan dan untuk sampel subjek dilakukan dengan undian. Sehingga diperoleh hasil sampel adalah 131 siswa. Data yang digunakan adalah data primer dan data sekunder. Data primer di dapat dari hasil kuesioner yang dibagikan untuk mengukur motivasi dan kebiasaan belajar, sementara data sekunder diperlukan untuk memperoleh hasil belajar siswa.

\section{Hasil dan Pembahasan}

\subsection{Proposi Responden Siswa Berdasrkan Kategori}

a. Motivasi Belajar

Kriteria yang telah ditentukan hasil penelitian yang diperoleh setelah memperoleh data motivasi belajar seperti tabel 1.

Tabel. 1 Proporsi Motivasi Belajar

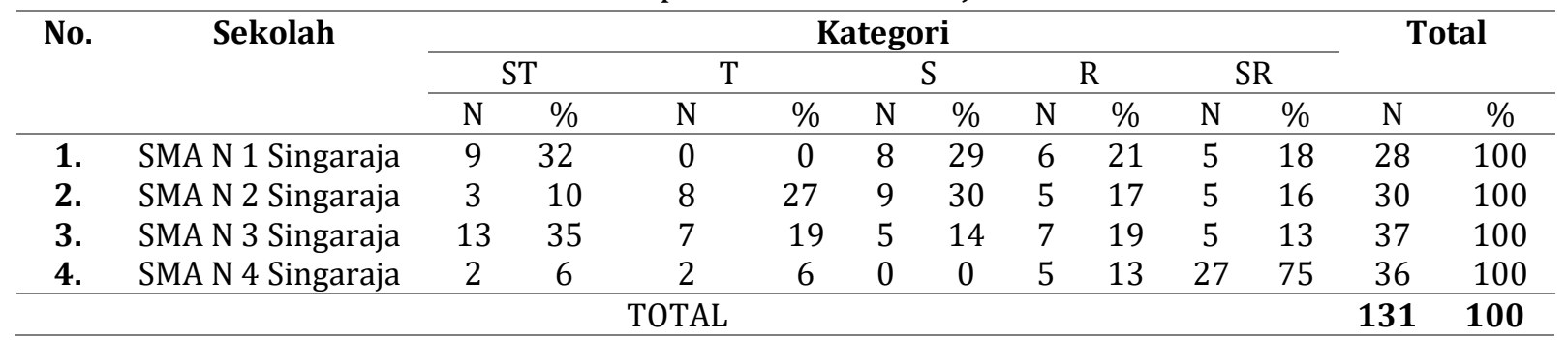

Sumber: Data Primer, 2017

Berdasarkan tabel di atas motivasi belajar siswa memiliki rata-rata berkategori sangat rendah.

b. Kebiasaan Belajar

Berdasarkan kritrria yang telah ditentukan hasil penelitian kebiasaan belajar terlihat pada tabel. 2 .

Tabel. 2 Proporsi Kebiasaan Belajar

\begin{tabular}{|c|c|c|c|c|c|c|c|c|c|c|c|c|c|}
\hline \multirow[t]{3}{*}{ No. } & \multirow[t]{3}{*}{ Sekolah } & \multicolumn{10}{|c|}{ Kategori } & \multirow{2}{*}{\multicolumn{2}{|c|}{ Total }} \\
\hline & & \multicolumn{2}{|c|}{ ST } & \multicolumn{2}{|c|}{$\mathrm{T}$} & \multicolumn{2}{|c|}{ S } & \multicolumn{2}{|c|}{$\mathrm{R}$} & \multicolumn{2}{|c|}{ SR } & & \\
\hline & & $\mathrm{N}$ & $\%$ & $\mathrm{~N}$ & $\%$ & $\mathrm{~N}$ & $\%$ & $\mathrm{~N}$ & $\%$ & $\mathrm{~N}$ & $\%$ & $\mathrm{~N}$ & $\%$ \\
\hline 1. & SMA N 1 Singaraja & 9 & 32 & 8 & 29 & 8 & 29 & 3 & 10 & 0 & 0 & 28 & 100 \\
\hline 2. & SMA N 2 Singaraja & 4 & 13 & 11 & 37 & 12 & 40 & 3 & 10 & 0 & 0 & 30 & 100 \\
\hline 3. & SMA N 3 Singaraja & 22 & 59 & 6 & 16 & 4 & 11 & 5 & 14 & 0 & 0 & 37 & 100 \\
\hline 4. & SMA N 4 Singaraja & 9 & 25 & 25 & 69 & 0 & 0 & 1 & 6 & 0 & 0 & 36 & 100 \\
\hline
\end{tabular}

Sumber: Data Primer, 2017 
Dari tabel di atas terlihat bahwa kebiasaan belajar siswa rata-rata berkategori tinggi.

c. Hasil Belajar

Berdasarkan kriteria yang telah ditentukan hasil penelitian Hasil Belajar siswa dapat terlihat pada Tabel. 3 .

Tabel. 3 Proporsi Hasil Belajar

\begin{tabular}{|c|c|c|c|c|c|c|c|c|c|c|c|c|c|}
\hline \multirow[t]{3}{*}{ No. } & \multirow[t]{3}{*}{ Sekolah } & \multicolumn{10}{|c|}{ Kategori } & \multirow{2}{*}{\multicolumn{2}{|c|}{ Total }} \\
\hline & & \multicolumn{2}{|c|}{ ST } & \multicolumn{2}{|c|}{$\mathrm{T}$} & \multicolumn{2}{|c|}{$S$} & \multicolumn{2}{|c|}{$\mathrm{R}$} & \multicolumn{2}{|c|}{ SR } & & \\
\hline & & $\mathrm{N}$ & $\%$ & $\mathrm{~N}$ & $\%$ & $\mathrm{~N}$ & $\%$ & $\mathrm{~N}$ & $\%$ & $\mathrm{~N}$ & $\%$ & $\mathrm{~N}$ & $\%$ \\
\hline 1. & SMA N 1 Singaraja & 8 & 29 & 0 & 0 & 6 & 21 & 1 & 4 & 13 & 46 & 28 & 100 \\
\hline 2. & SMA N 2 Singaraja & 6 & 20 & 5 & 17 & 13 & 43 & 0 & 0 & 6 & 20 & 30 & 100 \\
\hline 3. & SMA N 3 Singaraja & 7 & 19 & 7 & 19 & 11 & 30 & 7 & 19 & 5 & 13 & 37 & 100 \\
\hline 4. & SMA N 4 Singaraja & 4 & 11 & 4 & 11 & 5 & 14 & 11 & 31 & 12 & 33 & 36 & 100 \\
\hline \multicolumn{12}{|c|}{ TOTAL } & 131 & 100 \\
\hline
\end{tabular}

Sumber: Data Primer, 2017

Berdasarkan tabel tersebut terlihat bahwa hasil belajar siswa rata-rata berkategori sangat rendah.

\subsection{Uji Prasyarat}

a. Uji Normalitas Data

Sebelum melakukan pengujian hipotesis, dilakukan pengujian normalitas sebaran data dengan Uji Kolmogorov-Smirnov. Uji Kolmogorov-Smirnov digunakan untuk mengetahui apakah data berasal dari populasi yang berdistribusi normal atau tidak. Dengan bantuan aplikasi SPSS 22.0 for Windows. Dari perhitungan uji normalitas diperoleh nilai signifikan dari residual sebesar 0,200 yang artinya lebih besar dari 0,05. Hal ini memberikan kesimpulan bahwa data berasal dari populasi yang berdistribusi normal.

\section{b. Uji Linearitas Data}

Sebelum melakukan pengujian hipotesis, dilakukan pengujian linearitas data. Uji linearitas data dilakukan untuk mengetahui bentuk hubungan antara masing-masing variabel bebas dan variabel terikat yang terdiri dari variabel bebas yaitu motivasi belajar $\left(\mathrm{X}_{1}\right)$ dan kebiasaan belajar $\left(\mathrm{X}_{2}\right)$ dan variabel terikat yaitu hasil belajar (Y). Dengan bantuan aplikasi SPSS 22.0 for Windows. Dari hasi perhitungan uji linearitas motivasi belajar dengan hasil belajar diperoleh nilai signifikan sebesar 0,611 yang artinya lebih besar dari 0,05. Hal ini memberikan kesimpulan bahwa data linear. Sementara dari perhitungan uji linearitas kebiasaan belajar dengan hasil belajar dipeoleh nilai signifikan sebesar 0,069 yang artinya lebih besar dari 0,05. Hal ini memberikan kesimpulan bahwa data linear.

c. Uji Multikolinearitas

Sebelum melakukan pengujian hipotesis, dilakukan pengujian multikolinearitas data. Dengan bantuan aplikasi SPSS 22.0 for Windows. Dari perhitungan uji 
multikolinearitas diperoleh nilai Tolerance untuk motivasi dan kebiasaan belajar masing-masing 0,507 yang berarti lebih besar dari 0,1 dan nilai VIF untuk motivasi dan kebiasaan masing-masing 1,972 yang berarti lebih besar dari 1 dan kurang dari 10. Karena semua nilai Tolerance $<1$ dan semua nilai VIF lebih besar dari 1 dan kurang dari 10. Sehingga dapat disimpulkan tidak terjadi multikolinearitas.

\subsection{Uji Hipotesis Penelitian}

a. Pengujian Hipotesis I

H0: Tidak terdapat pengaruh positif antara motivasi belajar terhadap hasil belajar geografi siswa SMA Negeri di Kota Singaraja. Ha: Terdapat pengaruh positif antara motivasi belajar terhadap hasil belajar geografi siswa SMA Negeri di Kota Singaraja. Dengan bantuan aplikasi SPSS 22.0 for Windows diperoleh tabel hasil uji koefisien korelasi sebagai berikut.

Tabel. 4 Ringkasan Koefisien Korelasi X1 terhadap Y

\section{Correlations}

\begin{tabular}{llrr}
\hline & & MOTIVASI & \multicolumn{1}{c}{ HASIL } \\
\hline MOTIV & Pearson Correlation & 1 & $.858^{* *}$ \\
ASI & Sig. (2-tailed) & & .000 \\
& $\mathrm{~N}$ & 131 & 131 \\
HASIL & Pearson Correlation & $.858^{* *}$ & 1 \\
& Sig. (2-tailed) & .000 & \\
& $\mathrm{~N}$ & 131 & 131 \\
\hline **. Correlation is significant at the 0.01 level (2-tailed). \\
\hline
\end{tabular}

Dari tabel diatas diperoleh besar koefisien korelasi adalah 0,858 dengan kategori sangat kuat. Dengan kata lain hubungan antara motivasi dan hasil belajar sangat kuat. Berdasarkan perhitungan tersebut dapat disimpulkan bahwa terdapat pengaruh yang positif antara motivasi terhadap hasil belajar geografi siswa SMA Negeri di Kota Singaraja.

b. Pengujian Hipotesis II

H0: Tidak terdapat pengaruh yang positif antara kebiasaan belajar terhadap hasil belajar geografi siswa SMA Negeri di Kota Singaraja. Ha: Terdapat pengaruh yang positif antara kebiasaan belajar terhadap hasil belajar geografi siswa SMA Negeri di Kota Singaraja. Dengan bantuan aplikasi SPSS 22.0 for Windows diperoleh tabel hasil uji koefisien korelasi sebagai berikut.

Tabel. 5 Ringkasan Koefisien Korelasi X2 terhadap Y

Correlations

\begin{tabular}{llll}
\hline & & KEBIASAAN & HASIL \\
\hline KEBIA & Pearson Correlation & 1 & $.671^{* *}$ \\
SAAN & Sig. (2-tailed) & & .000 \\
& $\mathrm{~N}$ & 131 & 131 \\
HASIL & Pearson Correlation & $.671^{* *}$ & 1 \\
& Sig. (2-tailed) & .000 & \\
$\quad \mathrm{~N}$ & 131 & 131 \\
\hline **. Correlation is significant & at the & 0.01 & level $(2-$ \\
tailed). & & \\
\hline
\end{tabular}


Dari tabel diatas diperoleh besar koefisien korelasi adalah 0,671 dengan kategori kuat. Dengan kata lain hubungan antara kebiasaan dan hasil belajar kuat. Berdasarkan perhitungan tersebut dapat disimpulkan bahwa terdapat pengaruh yang positif antara kebiasaan belajar terhadap hasil belajar geografi siswa SMA Negeri di Kota Singaraja.

\section{d. Pengujian Hipotesis III}

H0: Tidak terdapat pengaruh positif secara bersama-sama antara motivasi dan kebiasaan belajar terhadap hasil belajar geografi siswa SMA Negeri di Kota Singaraja. Ha: Terdapat pengaruh positif secara bersama-sama antara motivasi dan kebiasaan belajar terhadap hasil belajar geografi siswa SMA Negeri di Kota Singaraja. Dengan bantuan aplikasi SPSS 22.0 for Windows diperoleh tabel hasil uji regresi berganda sebagai berikut.

Tabel. 6 Ringakasan Statistik Uji Regresi Berganda (X1 X2)*Y

\begin{tabular}{|c|c|c|c|c|c|c|}
\hline \multicolumn{7}{|c|}{ Coefficients $^{a}$} \\
\hline \multirow{2}{*}{\multicolumn{2}{|c|}{ Model }} & \multicolumn{2}{|c|}{$\begin{array}{l}\text { Unstandardiz } \\
\text { ed } \\
\text { Coefficients }\end{array}$} & $\begin{array}{l}\text { Standardi } \\
\text { zed } \\
\text { Coefficie } \\
\text { nts } \\
\end{array}$ & \multirow[b]{2}{*}{$\mathrm{t}$} & \multirow[b]{2}{*}{ Sig. } \\
\hline & & B & $\begin{array}{c}\text { Std. } \\
\text { Error }\end{array}$ & Beta & & \\
\hline 1 & (Consta & 70.1 & & & 88.3 & .00 \\
\hline & nt) & 83 & .794 & & 70 & 0 \\
\hline & MOTIVA & & & & 12.2 & .00 \\
\hline & SI & .072 & .006 & .764 & 05 & 0 \\
\hline & $\begin{array}{l}\text { KEBIAS } \\
\text { AAN }\end{array}$ & .021 & .010 & .135 & $\begin{array}{r}2.15 \\
4\end{array}$ & $\begin{array}{r}.03 \\
3\end{array}$ \\
\hline
\end{tabular}

Dari tabel diatas, dapat dilihat bahwa semua nilai signifikan pada variabel motivasi belajar adalah 0.000 kurang dari 0.05 dan nilai signifikan variabel kebiasaan 0,033 kurang dari 0,05, sehingga dapat disimpulkan terdapat pengaruh motivasi dan kebiasaan belajar terhadap hasil belajar. Sehingga diperoleh model regresi yang tepat sebagai berikut. $\mathrm{Y}=70,183+0,072 \mathrm{X} 1+0,021 \mathrm{X} 2$. Karena koefisien $\mathrm{X} 1$ bernilai positif $(0,072)$ sehingga dapat disimpulkan bahwa motivasi berpengaruh positif terhadap hasil belajar siswa. Hal ini berarti setiap peningkatan motivasi siswa maka terjadi peningkatan pula pada hasil belajar sebesar 0,072 poin. Begitu pula dengan kebiasaan belajar, Karena koefisien X2 bernilai positif $(0,021)$ sehingga dapat disimpulkan bahwa kebiasaan belajar berpengaruh positif terhadap hasil belajar siswa. Hal ini berarti setiap peningkatan kebiasaan belajar maka terjadi peningkatan pula pada hasil belajar sebesar 0,021 poin. 


\subsection{Koefisien Determinasi}

Dengan bantuan aplikasi SPSS 22.0 for Windows diperoleh tabel hasil uji koefisien determinasi sebagai berikut.

Tabel. 7 Koefesien Determinan

Model Summary ${ }^{\mathrm{b}}$

\begin{tabular}{|c|c|c|c|c|}
\hline \multicolumn{5}{|c|}{ Model Summary ${ }^{b}$} \\
\hline $\begin{array}{c}\text { Mode } \\
1\end{array}$ & $\mathrm{R}$ & $\begin{array}{c}\mathrm{R} \\
\text { Square }\end{array}$ & $\begin{array}{c}\text { Adjusted R } \\
\text { Square }\end{array}$ & $\begin{array}{l}\text { Std. Error } \\
\text { of the } \\
\text { Estimate }\end{array}$ \\
\hline 1 & $.864^{a}$ & .746 & .742 & 1.591 \\
\hline $\begin{array}{l}\text { a. Pred } \\
\text { b. Dep }\end{array}$ & $\begin{array}{l}\text { tors: } \\
\text { dent }\end{array}$ & $\begin{array}{l}\text { nstant) } \\
\text { iable: } H\end{array}$ & $\begin{array}{l}\text { KEBIASAAN } \\
\text { SIL }\end{array}$ & \\
\hline
\end{tabular}

Dari tabel diatas, dapat dilihat nilai dari koefisien determinasi yakni 0.746 . Dapat diartikan bahwa besarnya pengaruh atau kontribusi kebiasaan belajar dan motivasi belajar terhadap hasil belajar adalah sebesar $74,2 \%$ sisanya $26,8 \%$ adalah variabel lain diluar penelitian. Berdasarkan perhitungan tersebut dapat disimpulkan bahwa terdapat pengaruh secara bersama-sama antara motivasi dan kebiasaan belajar terhadap hasil belajar geografi siswa SMA Negeri di Kota Singaraja.

\subsection{Pengaruh Motivasi terhadap Hasil Belajar}

Motivasi belajar didefinasikan seabagai dorongan kehendak yang muncul dari dalam maupun dari luar individu selama melaksanakan aktivitas belajar berperan dalam menumbuhkan semangat belajar. Inensitas belajar siswa dipengaruhi oleh motivasi belajarnya. Seiap siswa berlomba-lomba berusaha seoptimal mungkin untuk memperoleh hasil belajar yang baik dalam hal yang demikian maka hasil belajar siswa dikatakan sebagai kebutuhan yang memunculkan motivasi dari dalam diri siswa untuk belajar. Dari hasil analisis korelasi diketahui bahwa terdapat pengaruh yang positif antara motivasi belajar terhadap hasil belajar geografi. Dari hasil penelitian ini diperoleh data bahwa korelasi motivasi belajar terhadap hasil belajar adalah sebesar 0,858 yang berarti memiliki korelasi atau hubungan yang sangat kuat. Dengan demikian maka motivasi belajar sangat berpengaruh terhadap hasil belajar siswa. Berdasarkan hasil tersebut terlihat bahwa hubungan motivasi belajar sangat kuat, maka perlu untuk meningkatkan motivasi belajar siswa agar hasil belajar siswa sesuai dengan apa yang diharapkan.

Motivasi sangat berpengaruh terhadap hasil belajar dikarenakan jika siswa memiliki motivasi untuk belajar maka akan berdampak positif terhadap hasil belajar siswa. Dengan adanya motivasi belajar yang kuat dalam diri siswa dapat mendorong siswa untuk lebih semangat dalam belajar sehingga siswa dapat lebih mudah menguasai materi pembelajaran. Untuk meningkatkan motivasi dalam diri siswa perlu dilakukan dorongan dari dalam diri berupa tekad untuk mencapai hasil belajar, selain itu dorongan dari luar, yaitu dengan cara memberikan penghargaan kepada siswa yang berprestasi seperti pemberian beasiswa, piagam, hadiah atau diadakan pemilihan siswa teladan dan 
berprestasi, dengan adanya hal-hal seperti ini maka siswa dapat terdorong untuk belajar lebih aktif sehingga memilikii hasil belajar yang diharapkan.

Siswa yang mempunyai motivasi tinggi akan memperoleh hasil belajar geografi yang lebih baik, jika dibandingkan dengan siswa yang mempunyai motivasi rendah. Motivasi belajar memiliki kontribusi besar terhadap berhasilnya kegiatan belajar. Siswa yang termotivasi dalam belajar akan menentukan tujannya sehingga kegiatan belajarnya lebih terarah. Siswa yang memiliki motivasi belajar yang besar, kemungkinan akan dapat melakukan belajar dengan sebaik-baiknya. Siswa yang mempunyai motivasi tinggi baik itu berasal dari motivasi intrinsik maupun motivasi ekstrinsik akan mampu menyelesaikan sebuah persoalan yang dihadapi sehingga mencapai hasil belajar yang bagus.

\subsection{Pengaruh Kebiasaan Belajar terhadap Hasil Belajar}

Kebiasaan belajar merupakan salah satu faktor yang mempengaruhi hasil belajar. Djaali (2008) mengemukakan bahwa kebiasaan belajar merupakan cara atau teknik yang menetap pada diri siswa pada waktu menerima pelajaran, membaca buku, mengerjakan tugas, dan pengaturan waktu untuk menyelesaikan kegiatan. Sudjana (2005) menyatakan keberhasilan siswa dalam mengikuti pelajaran sangat bergantung pada kebiasaan belajar yang teratur dan berkesinambungan. Siswa yang terbiasa mengatur cara dan gaya belajarnya akan lebih mudah dalam memahami pelajaran, melakukan perencanaan belajar, membuat catatan belajar, memiliki konsentrasi yang penuh dalam belajar, dan kuat dalam mengingat materi pelajaran. Dari hasil analisis tersebut diperoleh bahwa korelasi kebiasaan belajar terhadap hasil belajar sebesar 0,671 yang dapat dikatakan bahwa kebiasaan dan hasil belajar memiliki kategori hubungan atau korelasi yang kuat. Ini berarti varabel kebiasaan bejar memilki hubungan yang kuat dengan hasi belajar. Jika siswa memiliki kebiasaan yang baik maka hasil belajar siswa akan memuaskan.

Siswa yang telah menyiapkan alat, mental, dan fisiknya sebelum berangkat ke sekolah, jika dibiasakan akan menyebabkan siswa terhindar dari kehilangan konsentrasi belajar. Akibatnya siswa membiasakan diri untuk selalu konsentrasi saat belajar, meskipun jam pelajaran yang terakhir. Akan tetapi, jika siswa tidak menyiapkan alat, mental, dan fisik sebelum ke sekolah, kemungkinan siswa tersebut akan sulit konsentrasi saat belajar atau bisa jadi tugas yang seharusnya dikumpulkan tertinggal di rumah, karena tidak dipersiapkan terlebih dahulu.

Kebiasaan belajar dapat terwujud dan dilaksanakan siswa dalam kaitannya dengan aktivitas kehidupan yang nampak yaitu dalam bentuk tingkah laku khususnya dalam proses pembelajaran di sekolah. Kebiasaan ini tidak muncul dengan sendirinya, melainkan dikondisikan dan dibentuk melalui berbagai kegiatan baik melalui pengalaman, latihan dan belajar, yang dilakukan secara terus menerus, berkesinambungan dalam suasana pembelajaran. Bila kebiasaan belajar yang baik mucul pada setiap diri siswa maka akan berpengaruh baik juga terhadap hasil belajar siswa. 


\subsection{Pengaruh Motivasi dan Kebiasaan Belajar terhadap Hasil Belajar}

Dari paparan motivasi dan kebiasaan belajar di atas, terlihat bahwa motivasi dan kebiasaan belajar berpengaruh positif terhadap hasil belajar geografi maka dapat disimpulkan bahwa kedua faktor tersebut memberikan pengaruh yang positif terhadap hasil belajar geografi. Dapat dikatakan jika motivasi tinggi dan kebiasaan belajar baik akan mendapatkan hasil belajar yang memuaskan.

Hal tersebut dapat diketahui dari besarnya korelasi secara bersama sama antara motivasi dan kebiasaan belajar terhadap hasil belajar geografi siswa adalah sebesar 0,742. Dari besarnya korelasi diketahui bahwa secara bersama sama tingkat hubungan yang dimiliki adalah cukup kuat. Oleh karena itu maka diperoleh besarnya pengaruh kedua faktor tersebut secara bersama-sama adalah $74,2 \%$ sisanya $26,8 \%$ adalah variabel lain diluar penelitian.

Berdasarkan paparan tersebut, maka kita dapat memikirkan bagaimana cara meningkatkan motivasi dan kebiasaan belajar geografi siswa. Cara untuk meningkatkan motivasi dan kebiasaan belajar siswa bisa dimulai dari cara mengajar guru. Guru sebaiknya memilih model pembelajaran yang bisa menumbuhkan motivasi dan mengembangkan kebiasaan belajar yang baik pada siswa. Hal tersebut bertujuan agar motivasi dan kebiasaan belajar geografi siswa terangsang untuk timbul. Guru juga harus bisa menciptakan suasana yang kondusif dan menyenangkan bagi siswa untuk belajar sehingga siswa lebih termotivasi dan terbiasa untuk belajar dengan baik.

Selain dari faktor guru, keluarga juga memberikan peranan penting dalam meningkatkan motivasi dan kebiasaan belajar yang baik. Orang tua berperan dalam mendorong atau memotivasi anak untuk semangat dalam belajar khususnya dalam pelajaran geografi. Disamping itu, keluarga juga harus mampu menciptakan kebisaan belajar dirumah yang baik. Selain kedua faktor di atas, faktor intern juga tidak kalah penting. Anak harus memotivasi dan membiasakan diri untuk belajar dengan baik untuk memperoleh hasil yang baik pula.

\section{Simpulan dan Saran}

Berdasarkan hasil penelitian dan pembahasan dapat dikemukakan simpulan diantaranya (1) Terdapat pengaruh yang positif antara motivasi belajar terhadap hasil belajar geografi siswa SMA Negeri di Kota Singaraja. Motivasi belajar masih berkategori sangat rendah. (2) Terdapat pengaruh yang positif antara kebiasaan belajar siswa terhadap hasil belajar geografi siswa SMA Negeri di Kota Singaraja. Kebiasaan belajar siswa sudah berkategori tinggi. (3) Terdapat pengaruh yang positif secara bersamasama antara motivasi dan kebiasaan belajar siswa terhadap hasil belajar geografi siswa SMA Negeri di Kota Singaraja.

Berdasarkan hasil penelitian ini, maka dapat diajukan beberapa saran diantaranya (1) Guru hendaknya berusaha meningkatkan motivasi dan kebiasaan belajar siswa untuk meningkatkan hasil belajar siswa khususnya hasil belajar geografi. (2) Bagi siswa disarankan untuk selalu mengembangkan motivasi belajar dan meningkatkan kebiasaan belajar untuk meningkatkan hasil belajar khususnya hasil belajar geografi. (3) Bagi lembaga sekolah disarankan agar lebih memperhatikan, 
mengembangkan motivasi belajar dan meningkatkan kebiasaan belajar siswa secara keseluruhan. Selain itu lembaga sekolah hendaknya menentukan sebuah tindakan baru untuk membangun motivasi dan kebiasaan belajar siswa. (4) Bagi peneliti lain yang berminat terhadap temuan penelitian ini dapat melakukan pembuktian-pembuktian lebih mendalam dengan mengambil populasi dan sampel yang lebih besar.

\section{Daftar Rujukan}

Azainil. 2013. "Pengaruh Motivasi Belajar dan Kebiasaan Belajar terhadap Hasil Belajar Matematika Siswa SMPN di Kecamatan Samarinda Utara.

Djaali, H. 2009. Psikologi Pendidikan. Jakarta: PT Bumi Aksara.

Rifani, Irfan. 2013. Pengaruh Model Pembelajaran Learning Cycle dan Model Pembelajaran Solve Create And Share terhadap Pemahaman Konsep pada Pembelajaran Geografi di SMA. Skripsi. Universitas Pendidikan Indonesia.

Sardiman.2001.Interaksi dan Motivasi Belajar Mengajar. Jakarta:PT.Raja Grafindo

Slameto. 2003. Belajar dan Faktor-Faktor Yang mempengaruhinya. Jakarta: Rineka Cipta 